\title{
In-Silico Computational Screening of Siddha formulations Visha Sura Kudineer and Adathodai Kudineer against RNA dependent RNA polymerase of SARS CoV-2
}

\author{
Research Article
}

\section{Panneerselvam N R ${ }^{*}$, Anbarasan B ${ }^{2}$}

1. Professor, Department of Kuzhanthai Maruthuvam,

Sri Sairam Siddha Medical College and Research Centre, Sai Leo Nagar, Tambaram West, Chennai.

2. Lecturer, Department of Maruthuvam, National Institute of Siddha, Tambaram Sanatorium, Chennai.

\begin{abstract}
Background: Siddha Medicine is an important therapeutic option used for treating various respiratory viral infections and has antiviral herbs. Aim: The study aims to perform the In Silico computational studies of Phytoconstituents of Siddha formulation Visha Sura Kudineer and Adathodai Kudineer which are commonly used in the treatment of viral fever and respiratory tract infections and could be effective against the novel coronavirus disease. Methods: Autodock program was used for the molecular docking studies against RNA-dependent RNA polymerase (RdRP) (PDB ID: 6NUR). Results: A total of 9 compounds were screened, of these 4 compounds namely, Andrographolide of Visha Sura Kudineer and Anisotine, Apioside, and 1-(p-Methoxybenzoyl) aziridine of Adathodai Kudineer showed high binding affinity against RdRp. Conclusion: Based on further experiments and clinical trials, formulations Visha Sura Kudineer and Adathodai Kudineer could be effective in the treatment of COVID-19.
\end{abstract}

Key Words: Docking study, RdRp, Siddha formulation, Visha Sura Kudineer, Adathodai Kudineer, Viral replication.

\section{Introduction}

Coronaviruses $(\mathrm{CoVs})$ are a group of viruses belonging to the family coronaviridae which has two genera namely Coronavirus and Torovirus. They are enveloped and have an unsegmented genome of singlestranded positive RNA. (1). SARS-CoV-2, also called the novel coronavirus emerged as a potential threat to humans in 2019 (2). Coronaviruses have four genera i.e alpha, beta, gamma, and delta, among which $\alpha$ and $\beta$ variants gain more attention because of their ability to turn into major human pathogens (3). The genome of Coronaviruses, ranging from 26 to 32 kilobases in length (4). The size of the coronavirus is about $80-160 \mathrm{~nm}$ in diameter (5). The two-thirds portion of the genome of Coronavirus from the 5 -end expresses large replicase polyprotein which has RNA-dependent RNA polymerase (RdRp) which is the core enzyme of multiprotein replicase-transcriptase complex (RTC) essential for both transcription and replication of Coronavirus. nsp12-nsp8-nsp7 complex catalyzes the RNA synthesis where nsp12 showsRdRp activity and nsp8 \& nsp7 act as cofactors (6). Replication and transcription of the virus are facilitated by nsp12 harboring RNA-dependent RNA polymerase (RdRP) activity(7). To inhibit RdRp and viral replication targeting active sites of RdRp (ASP760 and ASP761) by antiviral

\section{* Corresponding Author:}

\section{Panneerselvam N R}

Professor, Department of Kuzhanthai Maruthuvam,

Sri Sairam Siddha Medical College and Research

Centre, Sai Leo Nagar,

Tambaram West, Chennai. India

Email Id: nrpannier@gmail.com drugs could be a potential therapeutic choice. (8) Phytocomponents when bind with the core amino acids of the RNA-dependent RNA polymerase with hydrogen bond will inhibit the target. The core amino acids of the target are 618 ASP, 760 ASP, and 761 ASP. RNA-dependent RNA polymerase (PDB)-6NUR mediates nonstructural protein (nsp 12) essential for viral replication. Thereby photo components that inhibit the target RdRp may act as a potential therapeutic agent for the management of COVID-19 and related symptoms. Visha sura kudineer (VSK) and Adathodai kudineer (AK) are Siddha herbal formulations that have been using for centuries. Visha Sura Kudineer contains Gingiber officinale Rosc.. Terminalia chebula Retz., Andrographis paniculata Burm.f, Justicia Adathoda Nees., Tinospora cordifolia willd., and Tricosanthes cucumerina Linn. The ingredients of Adathodai kudineer are Justicia adathoda Nees., Glycyrhiza glabra Linn., Abies webbiana Wall ex D. Don., and Piper longum Linn. Visha Sura Kudineer is used for treating various types of fevers (9) and Adathodai kudineer is used for the treatment of diseases of the respiratory tract, fever due to phlegm (10). Thus, the bioactive compounds of VSK and AK mentioned in Siddha literature were selected for evaluating their ability to inhibit RdRp of coronavirus.

\section{Materials and methods \\ Preparation of protein}

The crystalline structure of the target protein RNA dependent RNA polymerase (PDB)-6NUR was retrieved from protein data bank. The clean-up process for protein was done. The needed missing hydrogen atoms were also included. Different orientation of the lead molecules concerning the target protein was evaluated by Autodock 
program and the best dock pose was selected based on the interaction study analysis.

\section{Docking analysis}

Docking calculations were carried out for retrieved phytocomponents, Gingerenone-A, Arjungenin, Andrographolide, Anisotine, Tinosporide, Ascorbic acid, Apioside, 1-(p-Methoxybenzoyl)aziridine, and, Cepharadione B against target protein RdRp. With the help of AutoDock tools, Essential hydrogen atoms, Kollman united atom type charges, and solvation parameters were added. Affinity (grid) maps of $\times \times \AA$ grid points and 0.375 $\AA$ spacing were generated using the Autogrid program. AutoDock parameter set- and distance-dependent dielectric functions were utilized in the calculation of the van der Waals and the electrostatic terms, respectively. Docking simulations were done by using the Lamarckian genetic algorithm (LGA) and the Solis \& Wets local search method. The preliminary position, orientation, and torsions of the ligand molecules were set randomly. All rotatable torsions were freed during docking. Each docking experiment was derived from 2 different runs that were set to terminate after a maximum of 250000 energy evaluations. The population size was set to 150 . During the search, a translational step of $0.2 \AA$, and quaternion and torsion steps of 5 were applied (11-14).

\section{Figure 1: 3D- Structure of RNA dependent RNA} polymerase (PDB)-6NUR

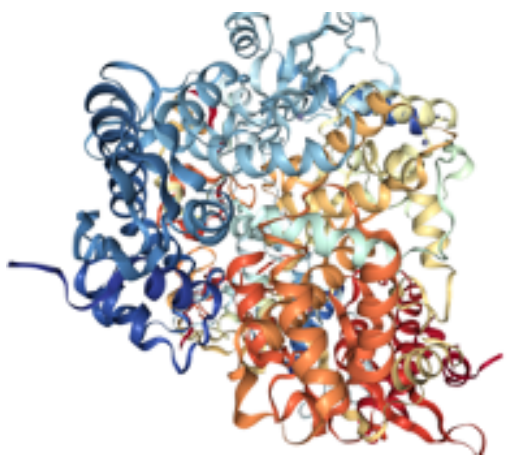

Figure 2: 2D and 3D Structure of Selected Ligands

Gingerenone-A

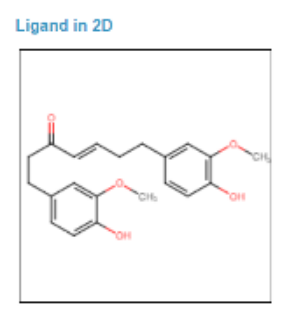

Ligand in 3D

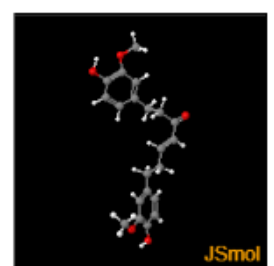

Anisotine

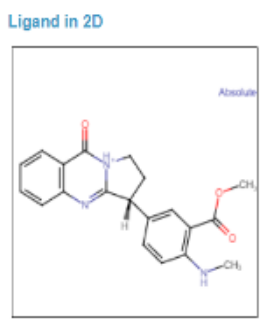

Ligand in $3 D$

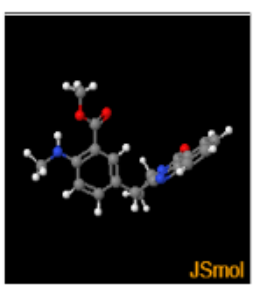

Apioside
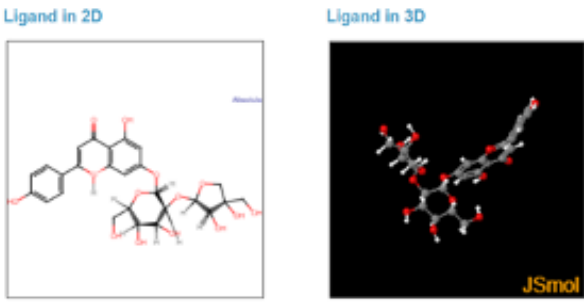

Arjungenin

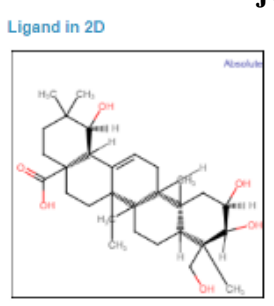

Tinosporide

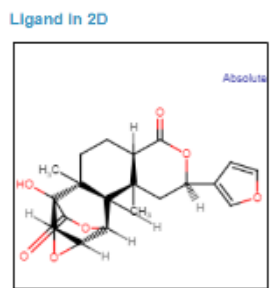

1-(p-Methoxybenzoyl) aziridine

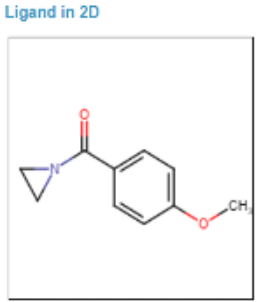

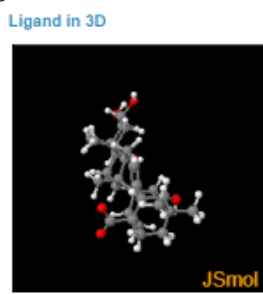
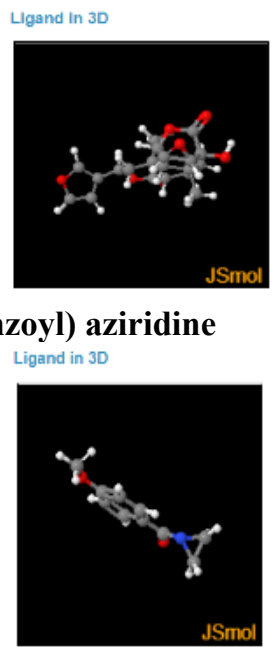

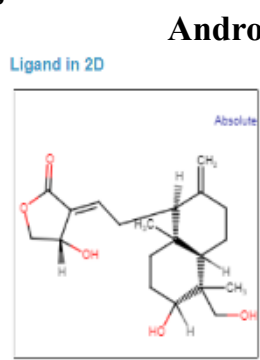

Andrographolide

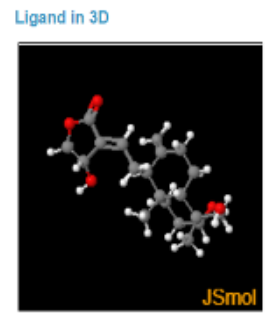

Ascorbic acid
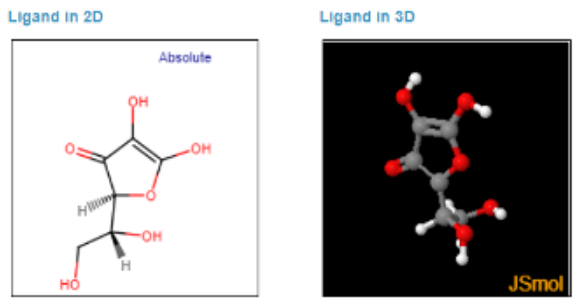

Cepharadione B
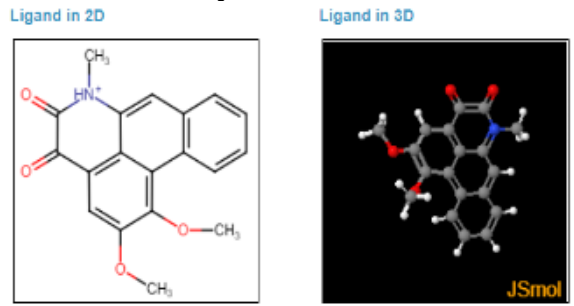

Table 1: Ligand Properties of the Compounds Selected for Docking Analysis

\begin{tabular}{|c|c|c|c|c|c|}
\hline Compound & $\begin{array}{c}\text { Molar weight g/ } \\
\text { mol }\end{array}$ & Molecular Formula & $\begin{array}{l}\text { H Bond } \\
\text { Donor }\end{array}$ & $\begin{array}{c}\text { H Bond } \\
\text { Acceptor }\end{array}$ & $\begin{array}{c}\text { Rotatable } \\
\text { bonds }\end{array}$ \\
\hline Gingerenone-A & $356.4 \mathrm{~g} / \mathrm{mol}$ & $\mathrm{C}_{21} \mathrm{H}_{24} \mathrm{O}_{5}$ & 2 & 5 & 9 \\
\hline Arjungenin & $504.708 \mathrm{~g} / \mathrm{mol}$ & $\mathrm{C}_{30} \mathrm{H}_{48} \mathrm{O}_{6}$ & 5 & 6 & 2 \\
\hline Andrographolide & $350.4 \mathrm{~g} / \mathrm{mol}$ & $\mathrm{C}_{20} \mathrm{H}_{30} \mathrm{O}_{5}$ & 3 & 5 & 3 \\
\hline Anisotine & $349.4 \mathrm{~g} / \mathrm{mol}$ & $\mathrm{C}_{20} \mathrm{H}_{19} \mathrm{~N}_{3} \mathrm{O}_{3}$ & 1 & 5 & 4 \\
\hline Tinosporide & $374.4 \mathrm{~g} / \mathrm{mol}$ & $\mathrm{C}_{20} \mathrm{H}_{22} \mathrm{O}_{7}$ & 1 & 7 & 1 \\
\hline Ascorbic acid & $176.12 \mathrm{~g} / \mathrm{mol}$ & $\mathrm{C}_{6} \mathrm{H}_{8} \mathrm{O}_{6}$ & 4 & 6 & 2 \\
\hline Apioside & 564.5 & $\mathrm{C}_{26} \mathrm{H}_{28} \mathrm{O}_{14}$ & 8 & 14 & 7 \\
\hline 1-(p-Methoxybenzoyl) aziridine & 177.20 & $\mathrm{C}_{10} \mathrm{H}_{11} \mathrm{NO}_{2}$ & 0 & 2 & 2 \\
\hline Cepharadione B & 321.3 & $\mathrm{C}_{19} \mathrm{H}_{15} \mathrm{NO}_{4}$ & 0 & 4 & 2 \\
\hline
\end{tabular}


International Journal of Ayurvedic Medicine, Vol 12 (3), 534-537

Table 2: Summary of the molecular docking studies of compounds against RNA dependent RNA polymerase (PDB)-6NUR

\begin{tabular}{|l|c|c|c|c|c|}
\multicolumn{1}{c|}{ Compounds } & $\begin{array}{c}\text { Binding Free energy } \\
\text { Kcal/mol }\end{array}$ & $\begin{array}{c}\text { Inhibition } \\
\text { constant Ki } \mathbf{\mu M} \\
(* \mathbf{m M})(* * \mathbf{m})\end{array}$ & $\begin{array}{c}\text { Electrostatic } \\
\text { energy Kcal/mol }\end{array}$ & $\begin{array}{c}\text { Intermolecular } \\
\text { energy Kcal/mol }\end{array}$ & $\begin{array}{c}\text { Interaction } \\
\text { Surface }\end{array}$ \\
\hline Gingerenone-A & -6.80 & 10.37 & -0.54 & -6.97 & 854.58 \\
\hline Arjungenin & -7.37 & 3.94 & -0.12 & -7.44 & 942.68 \\
\hline Andrographolide & -7.65 & 2.46 & -0.42 & -8.53 & 676.87 \\
\hline Anisotine & -6.89 & 8.92 & -0.19 & -7.49 & 743.51 \\
\hline Tinosporide & -6.14 & 31.53 & -0.31 & -6.71 & 671.39 \\
\hline Ascorbic acid & -5.62 & 75.71 & -0.97 & -4.62 & 387.17 \\
\hline Apioside & -7.04 & $6.93 *$ & -0.78 & -8.21 & 959.41 \\
\hline 1-(p-Methoxybenzoyl) & -4.05 & $1.08 * *$ & -0.01 & -4.64 & 489.57 \\
aziridine & -4.09 & $1.01 *$ & -0.03 & -468 & 452.30 \\
\hline Cepharadione B & & & & & 4 \\
\hline
\end{tabular}

Table 3: Amino acid Residue Interaction of Lead against RNA dependent RNA polymerase (PDB)-6NUR

\begin{tabular}{|c|c|c|c|c|c|c|c|c|c|c|}
\hline Molecules & Interaction & \multicolumn{9}{|c|}{ Amino Acid - Residue Interactions } \\
\hline Gingerenone-A & 2 & 553 ARG & 621 LYS & 623 ASP & $758 \mathrm{LEU}$ & 759 SER & 760 ASP & 761 ASP & & \\
\hline Arjungenin & 2 & 551 LYS & 553 ARG & 618 ASP & $621 \mathrm{LYS}$ & 623 ASP & 761 ASP & 798 LYS & 800 TRP & 811 GLU \\
\hline Andrographolide & 3 & 618 ASP & $758 \mathrm{LEU}$ & 760 ASP & 761 ASP & 798 LYS & 800 TRP & $811 \mathrm{GLU}$ & 814 SER & \\
\hline Anisotine & 3 & 618 ASP & 760 ASP & 761 ASP & 800 TRP & 811 GLU & 814 SER & & & \\
\hline Tinosporide & 2 & 551 LYS & 618 ASP & 761 ASP & 798 LYS & 800 TRP & 811 GLU & & & \\
\hline Ascorbic acid & 1 & 618 ASP & $621 \mathrm{LYS}$ & 622 CYS & 623 ASP & 798 LYS & & & & \\
\hline Apioside & 3 & 553 ARG & 618 ASP & $621 \mathrm{LYS}$ & 623 ASP & 624 ARG & 760 ASP & 761 ASP & 811 GLU & \\
\hline $\begin{array}{c}\text { 1-(p-Methoxybenzoyl) } \\
\text { aziridine }\end{array}$ & 3 & 617 TRP & 618 ASP & 619 TYR & 760 ASP & 761 ASP & 800 TRP & & & \\
\hline Cepharadione B & 1 & 761 ASP & 798 LYS & 800 TRP & $810 \mathrm{HIS}$ & $811 \mathrm{GLU}$ & & & & \\
\hline
\end{tabular}

\section{Results and Discussion}

The coronavirus is transmitted by aerosols. After infection, the virus binds and enters into the host cells by membrane fusion. Then, the virus penetrates the pulmonary alveolar epithelial cells, releases its contents, and undergoes replication (15). RNA-dependent RNA polymerase (RdRp), which is a highly versatile enzyme present within the RNA genome of the virus, contributes in the synthesis of RNA by catalyzing the RNA-template-dependent formation of phosphodiester bonds and thus for viral replication (16). Inhibition of $\mathrm{RdRp}$ is important to stop the replication of the virus, because RdRp is vital for the replication of virus. Since, it has no closely related host cell counterparts, $\mathrm{RdRp}$ inhibitors can avoid off-target side effects (17-18). The molecular docking studies were carried out for Gingerenone-A, Arjungenin, Andrographolide, Tinosporide, Ascorbic acid and Cepharadione B present in ingredients of Visha Sura Kudineer Chooranam and Anisotine, Apioside, and 1-(p-Methoxybenzoyl) aziridine present in ingredients of Adathodai Kudineer Chooranam against RdRp to identify the molecular interactions. All the phytochemical analogs were docked with RNA-dependent RNA polymerase by using the Autodock program.

A total of 9 bioactive lead compounds were retrieved from the herbs in accordance with the literature. On comparing binding affinities of the compounds, it was found that Andrographaloide showed the highest binding affinity of $-7.65 \mathrm{Kcal} / \mathrm{mol}$. Arjungenin showed the second-highest binding affinity with the binding free energy of $-7.37 \mathrm{Kcal} / \mathrm{mol}$ followed by Apioside and Anisotine with $-7.04 \mathrm{Kcal} / \mathrm{mol}$ and
$-6.89 \mathrm{Kcal} / \mathrm{mol}$. The compounds Andrographolide, Anisotine, Apioside, and 1-(p-Methoxybenzoyl) aziridine shared two active site amino acids in common. Though the compound Arjungenin showed high binding energy than 1-(p-Methoxybenzoyl) aziridine while considering the interactions, the amino acid residue found in common was only two in Arjungenin. But the compound 1-(p-Methoxybenzoyl) aziridine shared three amino acids in common though it has the binding energy of $-4.05 \mathrm{Kcal} / \mathrm{mol}$. So, the lead compounds Andrographolide of Visha Sura Kudineer, and Anisotine, Apioside, and 1-(p-Methoxybenzoyl) aziridine of Adathodai Kudineer possess $100 \%$ binding efficacy by interacting with all three-core target amino acid (618 ASP, 760 ASP, 761 ASP) present on the target receptor RdRp. Among these four compounds, andrographolide and anisotine also have potential inhibitory activity of spike protein of Sars-Cov-2 (19-20). Andrographolide also has potency to inhibit pulmonary inflammation on acute lung injury in mice (21) and suppresses inflammation of lungs induced by Haemophilus influenza infection in mice model (22). Another docking study revealed that revealed that anisotine has the potential of inhibiting the proteolytic activity of SARS CoV-2 main protease (23). In this study, their potential of inhibiting RdRp of coronavirus has also been determined.

\section{Conclusion}

Based on the results of the computational analysis it was concluded that the compound's Andrographolide of Visha Sura Kudineer has significant binding efficacy against RdRp. Anisotine, Apioside, and 
1-(p-Methoxybenzoyl) aziridine present in the herbal ingredients of the Adathodai kudineer reveals significant binding efficacy against the target protein. It can be concluded that herbs Andrographis paniculate Burm.f,, Justicia Adathoda Nees., Abies Webbiana, Wall ex D. Don., and Glycyrrhiza glabra Linn., exert promising $\mathrm{RdRp}$ enzyme inhibition potential, thereby halt the viral replication. Based on the results of this current study Visha Sura Kudineer and Adathodai Kudineer, can be effective in the treatment of Covid-19. Further studies are needed to know the efficacy of VSK and AK against Covid 19.

\section{Conflict of Interest}

Nil

\section{References}

1. Arora D R, Brij Bala Arora, Textbook of microbiology, 5ed. Chennai; CBS Publishers and Distributors Pvt Ltd; 2017; 500p.

2. Zheng J. SARS-CoV-2: an Emerging Coronavirus that Causes a Global Threat. Int J Biol Sci. 2020 Mar 15;16(10):1678-1685. doi: 10.7150/ijbs.45053. PMID: 32226285; PMCID: PMC7098030.

3. Li H, Liu SM, Yu XH, Tang SL, Tang CK. Coronavirus disease 2019 (COVID-19): current status and future perspectives. Int $\mathrm{J}$ Antimicrob Agents. 2020 May;55(5):105951.

4. Wang H, Li X, Li T, Zhang S, Wang L, Wu X, Liu J. The genetic sequence, origin, and diagnosis of SARS-CoV-2. Eur J Clin Microbiol Infect Dis. 2020 Sep;39(9):1629-1635.

5. Yang, Y., Xiao, Z., Ye, K. et al. SARS-CoV-2: characteristics and current advances in research. Virol J 17, 117 (2020).

6. Gaurav A, Al-Nema M. Polymerases of Coronaviruses: Structure, Function, and Inhibitors. Viral Polymerases. 2019:271-300.

7. Jiang $Y$, Yin $\mathrm{W}, \mathrm{Xu}$ HE. RNA-dependent RNA polymerase: Structure, mechanism, and drug discovery for COVID-19. Biochem Biophys Res Commun. 2021 Jan 29;538:47-53.

8. Aftab, S.O., Ghouri, M.Z., Masood, M.U. et al. Analysis of SARS-CoV-2 RNA-dependent RNA polymerase as a potential therapeutic drug target using a computational approach. J Transl Med 18, 275 (2020).

9. Velusamy K, Jagajothi Pandiyan S, Meenatchisundara moorthhy K. Theran Kudineer; 2ed. New Delhi; Central Council for research in Ayurvedic Sciences; 1996. 8P.

10. Kuppusamy Mudhaliyar K N. Uthamarayan K S. Siddha Vaithiya Thirattu. 1st ed. Chennai;Department of India Medicine and homoeopathy; $1998 ; 294 p$.

11. Bikadi Z, Hazai E. Application of the PM6 semiempirical method to modeling proteins enhances docking accuracy of AutoDock. J Cheminform. 2009 Sep 11;1:15.
12. Halgren, T.A. (1996), Merck molecular force field. I. Basis, form, scope, parameterization, and performance of MMFF94. J. Comput. Chem., 17: 490-519.

13. Morris, G.M., Goodsell, D.S., Halliday, R.S., Huey, R., Hart, W.E., Belew, R.K. and Olson, A.J. (1998), Automated docking using a Lamarckian genetic algorithm and an empirical binding free energy function. J. Comput. Chem., 19: 1639-1662.

14. Francisco J. Solis, Roger J.-B. Wets, Minimization by Random Search Techniques. Mathematics of Operations Research 6 (1) 19-30.

15. Parasher A. COVID-19: Current understanding of its Pathophysiology, Clinical presentation and Treatment Postgraduate Medical Journal 2021;97:312-320.

16. Venkataraman S, Prasad BVLS, Selvarajan R. RNA Dependent RNA Polymerases: Insights from Structure, Function and Evolution. Viruses. 2018 Feb 10;10(2):76.

17. Jiang $Y$, Yin $\mathrm{W}, \mathrm{Xu}$ HE. RNA-dependent RNA polymerase: Structure, mechanism, and drug discovery for COVID-19. Biochem Biophys Res Commun. 2021 Jan 29;538:47-53.

18. Zhu W, Chen CZ, Gorshkov K, Xu M, Lo DC, Zheng W. RNA-Dependent RNA Polymerase as a Target for COVID-19 Drug Discovery. SLAS Discov. 2020 Dec;25(10):1141-1151.

19. Enmozhi SK, Raja K, Sebastine I, Joseph J. Andrographolide as a potential inhibitor of SARS$\mathrm{CoV}-2$ main protease: an in silico approach. $\mathrm{J}$ Biomol Struct Dyn. 2021 Jun;39(9):3092-3098.

20. Kar P, Kumar V, Vellingiri B, Sen A, Jaishee N, Anandraj A, Malhotra H, Bhattacharyya S, Mukhopadhyay S, Kinoshita M, Govindasamy V, Roy A, Naidoo D, Subramaniam MD. Anisotine and amarogentin as promising inhibitory candidates against SARS-CoV-2 proteins: a computational investigation. J Biomol Struct Dyn. 2020 Dec 11:1-11.

21. Peng S, Hang N, Liu W, Guo W, Jiang C, Yang X, $\mathrm{Xu}$ Q, Sun Y. Andrographolide sulfonate ameliorates lipopolysaccharide-induced acute lung injury in mice by down-regulating MAPK and NF$\kappa B$ pathways. Acta Pharm Sin B. 2016 May;6(3):205-11.

22. Tan WS, Peh HY, Liao W, Pang $\mathrm{CH}$, Chan TK, Lau $\mathrm{SH}$, Chow VT, Wong WS. Cigarette SmokeInduced Lung Disease Predisposes to More Severe Infection with Nontypeable Haemophilus influenzae: Protective Effects of Andrographolide. J Nat Prod. 2016 May 27;79(5):1308-15.

23. Ghosh R, Chakraborty A, Biswas A, Chowdhuri S. Identification of alkaloids from Justicia adhatoda as potent SARS CoV-2 main protease inhibitors: An in silico perspective. J Mol Struct. 2021 Apr 5;1229:129489. 